\title{
A tradução da poesia ilustrada de Wilhelm Busch no Brasil: Proposta de um novo padrão métrico-acentual
}

\author{
[The Translation of Wilhelm Busch's Illustrated Poetry in Brazil: \\ Towards a New Accentual-Metrical Pattern] \\ http://dx.doi.org/10.1590/1982-883787109
}

Simone H. de Mello ${ }^{1}$

\begin{abstract}
The present article recapitulates the Brazilian translations of Wilhelm Busch and points out that some publication circumstances have led to a biased reception of his work exclusively as children's literature in this country. Among other translation strategies which could contribute to extend the reading public of his work to an adult audience, this article proposes that the Knittelvers should be translated into Portuguese as a jambic ten-syllable line. An annotated translation of Busch's illustrated poem "Hänsel und Gretel", in this metric pattern, tests in which extent the conscious choice of rhythm and the attainment of cultural associations triggered by it can intensify the ironical effect of this mock fairy tale.
\end{abstract}

Keywords: translation; Wilhelm Busch; poetry; metrics; rhythm

Resumo: Este artigo recapitula as traduções de Wilhelm Busch publicadas no Brasil e aponta que determinadas circunstâncias de publicação levaram a uma recepção unilateral de sua obra exclusivamente como literatura infantil nesse país. Entre outras estratégias que poderiam estender para uma faixa etária adulta o público leitor da poesia humorística buschiana, propõese que o Knittelvers seja traduzido para o português como decassílabo iâmbico. Uma tradução anotada do poema "Hänsel und Gretel" nesse padrão métrico-acentual testa em que medida a escolha consciente de um ritmo e o aproveitamento de associações culturais desencadeadas por ele podem destacar o efeito irônico desse pseudoconto-de-fada.

Palavras-chave: tradução; Wilhelm Busch; Brasil; versificação; ritmo.

Zusammenfassung: Dieser Artikel rekapituliert die brasilianischen Übersetzungen von Wilhelm Busch und weist darauf hin, dass manche Veröffentlichungsumstände in diesem Land zu einer einseitigen Rezeption seines Werkes ausschließlich als Kinderliteratur geführt haben. Unter anderen Ü̉bersetzungsstrategien, die zu einer Erweiterung seiner Rezeption durch ein

\footnotetext{
${ }^{1}$ Universidade Federal de Santa Catarina (UFSC), Programa de Pós-Graduação em Estudos da Tradução (PGET); Casa Guilherme de Almeida - Centro de Estudos de Tradução Literária (instituição do Estado de São Paulo). Email: simonehomemdemello@gmail.com
} 
Mello, Simone H. - Wilhelm Busch no Brasil

erwachsenes Lesepublikum beitragen könnten, wird vorgeschlagen, dass der Knittelvers ins Portugiesische als ein jambischer zehnsilbigen Vers übersetzt wird. Eine kommentierte Übersetzung der Bildergeschichte "Hänsel und Gretel" in diesem metrischen Muster überprüft in welchem Maß der bewusste Gebrauch von Rhythmus und die Beachtung mancher kultureller Assoziationen von Metrik die ironische Wirkung dieses Pseudo-Märchens verstärken können.

Stichwörter: Übersetzung; Wilhelm Busch; Brasilien; Verslehre; Rhythmus.

O pintor e poeta alemão Wilhelm Busch (1832-1908), que - à parte de seus poemas líricos e de suas pinturas - se tornou amplamente conhecido por suas histórias em verso ilustradas, foi apresentado ao público brasileiro em 1871, com o livro Historias burlescas e instructivas, em versos coxos esdruxolos, e de pé quebrado, publicado pela Tipografia Laemmert, no Rio de Janeiro. Segundo as fontes, essa edição (da qual a autora não localizou nenhum exemplar) incluía a tradução das histórias buschianas "Diogenes und die bösen Buben von Korinth" (Do philosopho Diogenes e dos máos meninos de Corintho), "Die Rache des Elephanten" (Da vingança do elephante da Africa) e "Der neidische Handwerksbursch" (Do rico comilão e do pobretão invejoso), erroneamente atribuídas ao autor de Der Struwwelpeter, além de uma história de Fritz Steub (BUSCH 2002: 1146). Igualmente não se encontraram referências ao tradutor dessas histórias para o português. Trinta anos depois, a mesma editora Laemmert publicaria a tradução de Max und Moritz - Eine Bubengeschichte in sieben Streichen (1865) por Olavo BILAC, sob o título de Juca e Chico - História de dois meninos em sete travessuras. Durante os anos 1940, Guilherme de ALMEIDA ampliou o repertório de textos buschianos em português por meio da tradução de vinte histórias ilustradas, agrupadas em cinco volumes da série Busch² ${ }^{2}$, uma coleção da Editora Melhoramentos (São Paulo) direcionada ao público infantil, com títulos do artista que dava nome à série e de outros autores. Na década de 1950, a coleção ganhou novos títulos de Wilhelm Busch, em tradução de Antonio de Pádua Morse. ${ }^{3}$ Todas as traduções de Bilac, Almeida e Morse integrantes da série Busch foram republicadas pela Melhoramentos na

\footnotetext{
${ }^{2}$ Corococó e caracacá e outras histórias, 1943 ("O sapo e dois patinhos", "O camponês e o moleiro", "Corococó e Caracacá", "O lambe-lambe"); O camundongo e outras historietas, 1943 ("O camundongo", "O caipira e seu bezerro", "Pedro malvado", "O ninho de urubu", além de "A pulga - uma história sem palavras", composta apenas de ilustrações e título); O fantasma lambão, 1943 ("O fantasma lambão", "O dente furado", "O primo Chico e o burro", "Os dois ladrões"); A mosca e outras historietas, 1946 ("A mosca", "O grande virtuose", "A pitada de rapé", "O furta-linguiça"); A cartola, 1949 ("Estória gelada", "O beberrão", "A cartola").

${ }^{3}$ O corvo, 1952 ("O corvo", "O coelhinho da sorte"); O chorão e outras histórias, 1953 ("O chorão", "Os óculos", "A chucha").
} 
Mello, Simone H. - Wilhelm Busch no Brasil

série Juca e Chico, editada na década de 1970. Esta nova coleção infantil incorporou traduções de Maria Thereza Cunha Giácomo. ${ }^{4}$ Em anos mais recentes, publicaram-se ainda retraduções de Max und Moritz, por Sigfrid FröMMING (2009) e Claudia CAVAlCANTi (2012).

A tradução de Olavo Bilac, sob o pseudônimo de Fantásio, introduziu no Brasil, no início do século XX, uma obra infantil pela qual Busch se tornara conhecido de um grande público leitor na Alemanha, trinta e seis anos antes. ${ }^{5} \mathrm{Na}$ tradução bilaquiana se reconhecem traços edificantes típicos da literatura infantil. Em seus estudos acadêmicos sobre a recepção de Wilhelm Busch no Brasil, Gerson Luís POMARI (1999; 2008) reconhece no primeiro Juca e Chico brasileiro a "proeminência dos aspectos didáticomoralizadores" (POMARI 2008: 107), em detrimento das "potencialidades de significação original da obra" (id., ibid.), traço aquele também reconhecido na "produção bilaquiana voltada para as crianças, [...] claramente marcada pela intenção didática e patriótica" (POMARI 1999: 140). O universo de recepção infantil também é o pano de fundo da análise de Max und Moritz por Sigfrid FRÖMMING (2009: 124), sendo sua proposta de tradução voltada para um "público alvo [...] formado por crianças em torno de 4 a 10 anos". Da mesma forma, As travessuras de Juca e Chico, na versão de Claudia Cavalcanti, foi publicada na série infantil "livros da ilha", da Editora Iluminuras, com um prefácio dirigido a crianças. A introdução de Busch no Brasil por meio de sua principal obra infantil, em um contexto tradutório e mercadológico estritamente voltado para crianças, foi sucedida pela tradução de uma série de outros poemas ilustrados do autor, em grande parte publicados originariamente no semanário humorístico Fliegende Blätter (editado de 1845 a 1944, em Munique) e na série de edições de estampas Münchener Bilderbogen (publicada na mesma cidade, entre 1848 a 1905), ambos destinados a um público leitor adulto ou misto. Nas décadas de 1940/1950 e de 1970, a Editora Melhoramentos lançou traduções dessas histórias justamente no contexto das já mencionadas séries Busch e Juca e Chico. (Vide anexo:

\footnotetext{
${ }^{4} \mathrm{O}$ macaco e o moleque, s/d ("O macaco e o moleque", "A vingança do elefante", "A raposa", "O professor distraído", além de duas traduções de Guilherme de Almeida aqui republicadas); O fantasma lambão, s/d ("O porco e o camponês", "O rato sabido", "Diógenes e os meninos de Corinto", "O que aconteceu na noite de São Silvestre ou por que seu Fedolino deixou para sempre o vício de beber", além de duas traduções de Guilherme de Almeida e outra não assinada); Rico, o mico, s/d (tradução parcial de uma história ilustrada mais longa); O trenó de Joãozinho, s/d ("O trenó de Joãozinho", "O cão fiel", "O passeio de Adélia", "Novas aventuras de Rico, o mico").

${ }^{5}$ A primeira edição de Max und Moritz (1865), lançada após o fracasso editorial de Bilderpossen, um ano antes, teve uma tiragem de 4 mil exemplares. Sete anos depois, o livro já estava na quinta edição. (Ver PAPE 1977: 35-36.)
} 
Primeiras edições brasileiras de Wilhelm Busch). Esse projeto editorial sedimentou a inserção de Wilhelm Busch no Brasil como um autor estritamente infantil. A análise dos elementos paratextuais das duas coleções da Melhoramentos, realizada por Pomari em sua tese sobre o contexto de recepção de Busch no Brasil, comprova a constância das "descrições do teor moralizador e pedagogizante das histórias ilustradas" e sua "classificação prévia como obra destinada ao público infantil" (POMARI 2008: 113). Os títulos dos livros de ambas as coleções e das histórias que os integram, com uma certa incidência de diminutivos e aumentativos ausentes no original, também apontam para esse redirecionamento dos escritos buschianos ("Die beiden Enten und der Frosch" / "O sapo e os dois patinhos"; "Der Hahnenkampf, eine Fabel" / "Corococó e Caracacá", "Die Rutschpartie" / "O trenó do Joãozinho", "Eugen, der Honigschlecker" / "O fantasma lambão").

A veiculação das histórias ilustradas de Busch como leitura para crianças não caracteriza apenas a recepção brasileira, mas também se reconhece na comercialização de sua obra na Alemanha. Segundo aponta Walter PAPE:

As atuais editoras de literatura infantil e os catálogos de livros de segunda mão
oferecem todas as histórias, sem distinção, a crianças (geralmente com exceção de
"Fromme Helene", "Bilder zur Jobsiade" e "Pater Filuzius"). Certamente todas as
histórias ilustradas eram, de fato, lidas por crianças, sobretudo porque as obras de
Busch passaram a ser propagadas (a partir de 1884) como Humoristischer Hausschatz.
Em sentido estrito, com base na intenção autorial, os livros infantis são Bilderpossen
(1864), Max und Moritz (1865), Stippstörchen für Äuglein und Öhrchen (1880), Der
Fuchs. Die Drachen (1881), além de Fipps, der Affe für Kinder (1879), versão não
editada em vida. "Hans Huckebein" (1867) foi primeiramente publicado em uma
revista para famílias, podendo ter sido concebido como leitura para crianças. Plitsch
und Plum ocupa um lugar especial, por ter sido planejado como livro infantil, mas por
fim ter se "alinhado à série de escritos para adultos" ([Carta de Otto] Bassermann a
Busch, 17/03/1882). (PAPE 2007: 25-26)

As histórias de Wilhelm Busch explicitamente destinadas a crianças ocupam, portanto, um lugar reduzido em sua extensa obra de poesia ilustrada. Em decorrência de seu forte apelo lúdico, da expressividade das ilustrações, do esquematismo do enredo, da graça dos versos rimados, do humor das cenas, os poemas ilustrados desse autor considerado precursor das histórias em quadrinho ${ }^{6}$ oferecem grande atratividade como leitura infantil. O fato de Busch poder ser lido por crianças, sem maiores dificuldades, não o

\footnotetext{
${ }^{6}$ Sobre a importância de Busch como precursor das histórias em quadrinhos, ver Joseph KRAUS (2009: 78).
} 
torna, no entanto, um autor estritamente infantil. A apreensão do estrato lúdicohumorístico de suas histórias pode ocorrer mesmo em leituras que ignorem a ironia na relação entre texto e imagem, o sarcasmo na representação de diversos tipos humanos, a crítica social e anticatólica, a problematização de temas de época (como o cientificismo e o darwinismo), entre outros elementos que perfazem a complexidade literária da poesia ilustrada de Wilhelm Busch. ${ }^{7}$

A recuperação da obra de Busch para um público tanto infantil como adulto, análogo ao público leitor que o lia na segunda metade do século XIX, oferece dificuldades por diversos motivos. Em primeiro lugar, o prazer estético proporcionado por seus desenhos virtuosos, embora persista ainda hoje, perdeu o sabor da novidade. A atratividade das histórias ilustradas, impressas em semanários ou séries de estampas, numa época em que as pessoas eram bem menos expostas à imagem, dificilmente se pode resgatar hoje. Além disso, a inovação que representava na época de Busch o gênero híbrido das histórias ilustradas, alimentado pela tensão entre desenho e palavra, já se tornou parte integrante do repertório de leitura contemporâneo, após o desenvolvimento secular das histórias em quadrinhos e diante da atual oferta de gêneros narrativos multimídia. Essas dificuldades se aplicam tanto aos leitores de língua alemã quanto aos leitores de suas traduções hoje.

Para os leitores de língua alemã, no entanto, a familiaridade com o universo de referências das histórias de Busch garante maior acesso do público adulto. No caso da veiculação de sua obra em outras culturas, esse acesso teria que ser assegurado por paratextos que reconstituíssem o contexto histórico-social que motivou muitas das estilizações caricaturais de suas histórias, chave para a compreensão de seu teor crítico e de seu alcance intelectual e artístico. Uma edição comentada da obra de Busch poderia compensar a veiculação unilateral que ele teve no Brasil, restrita até agora ao âmbito da literatura infantil, mas - por outro lado - ficaria limitada ao público adulto. O redirecionamento da obra de Busch apenas por meio de paratextos e peritextos, embora bem-vindo e necessário, implicaria uma nova restrição de seu público-alvo.

Nesse contexto, caberia refletir o papel que a tradução poderia ter na ampliação do público leitor de Wilhelm Busch. Evitar traços afetivos da linguagem infantil ausentes no original certamente representaria uma contribuição importante. Tanto a escolha de nomes próprios (Joãozinho para Hans [Cunha], Carlos lambareiro ou Lambe-Lambe

\footnotetext{
${ }^{7}$ Para uma descrição do contexto histórico legível na obra de Wilhelm Busch, ver POMARI (2008: 19ss).
} 
para Karl [Almeida]) e a denominação de animais (Totó para Schnauzel [Almeida]) poderiam ser menos restritivas, como também se poderia evitar o uso de diminutivos inexistentes em Busch ("Die Luft ist kühl, es weht der Wind / Der Bauer zieht zur Mühl' geschwind ": "Bem cedo, com seu burrinho, / o camponês vai ao moinho." [Almeida]; "Sieh da, zwei Enten jung und schön, / Die wollen an den Teich hingehn.": "Vejam que lindos patinhos! / Vão tomar banho sozinhos." [Almeida]). A eliminação de elementos infantilizadores até certo ponto propagados nas traduções brasileiras de Busch não as transformaria automaticamente, no entanto, em textos para adultos.

Uma estratégia possivelmente profícua, na busca de uma tradução que dialogue tanto com crianças como com adultos, poderia ser a investigação do tipo de apelo nas histórias de Busch que atinge diversas faixas etárias. Enquanto a agudeza crítica do autor atrai primordialmente leitores adultos e a simplicidade narrativa de suas histórias conquista a atenção de um público primordialmente infantil, o apelo lúdico e humorístico parece atingir ambos os lados. Para essa finalidade investigativa, propõe-se aqui uma breve leitura das estratégias de humor em Busch à luz das reflexões de seu contemporâneo Henri Bergson sobre o riso.

Diversos recursos geradores de comicidade analisados por Bergson em Le rire Essai sur la signification du comique (1900) se reconhecem na constituição do enredo e na caracterização dos personagens das histórias buschianas: a inversão de papéis antagônicos (BERGSON 1924: 44), sobretudo entre o agressor e vítima; a transposição de um personagem para uma situação indigna do seu status (id.: 55); o travestimento, com a transferência de comportamentos humanos para os animais e vice-versa (id.: 25); a transformação da figura humana em coisa (id.: 30); o desvio da atenção das ações para os gestos (id.: 63); entre outros.

Aqui se enfocará mais detalhadamente, no entanto, um elemento discursivo associado aos traços da insensibilidade e da indiferença, a partir dos quais Bergson desenvolve sua reflexão sobre o riso.

Assinalemos agora, como um sintoma não menos digno de nota, a insensibilidade que normalmente acompanha o riso. Parece que o cômico só pode ter ressonância sob a condição de se chocar contra uma superfície de alma bem calma, bem íntegra. A indiferença é seu ambiente natural. Mantenham um distanciamento, assistam à vida como um espectador indiferente: e muitos dramas se tornarão uma comédia. (BERGSON 1924: 10-11; tradução da autora) 
O que se nota nas histórias ilustradas de Wilhelm Busch, tanto as destinadas a um público infantil quanto as dirigidas ao leitor adulto, é uma discrepância entre a expressividade, não raro drástica, das imagens, e a impassibilidade descritiva do texto. Essa discrepância, geradora de uma distância irônica constante, coincide com o que BERGSON denomina "o mecânico agregado ao vivo" (1924: 23, tradução da autora). A vivacidade das cenas desenhadas, repletas de imprevistos e oscilações, tem como contraponto o tom inalterável, aparentemente mecânico, dos versos (ou legendas, ou textos em prosa, em um número reduzido de histórias). No caso dos poemas, o automatismo do tom é exacerbado pela regularidade métrica, acentual e rímica do Knittelvers estrito, padrão versificatório utilizado por Busch na grande maioria de suas histórias ilustradas.

O Knittelvers estrito consiste de versos de oito sílabas terminados em rimas masculinas ou de nove sílabas, em rimas femininas, emparelhadas, enquanto o chamado Knittelvers livre demonstra maior variação silábica. Amplamente utilizado pelos autores de língua alemã na poesia lírica, épica e dramática de tom elevado durante o século XVI, especialmente pelo poeta Hans Sachs (1494-1576), o Knittelvers foi classificado como um verso menor posteriormente, pela poética de Martin Opitz, e rejeitado como um padrão não elevado pelos poetas do século XVII. Sua forma livre continuou sendo cultivada em manifestações poéticas da tradição oral e na poesia popular. Após ter sido resgatado por J. C. Gottsched no século XVIII, foi definitivamente reabilitado por Goethe, que passou a utilizá-lo a partir dos anos 1770, empregando-o no Urfaust, no Faust e no West-Östlicher Diwan, entre outras obras ${ }^{8}$. Foram Goethe e seus contemporâneos que introduziram outra regularidade ao padrão: a constância de quatro acentos, sendo que o Knittelvers estrito passaria a ser composto por pés binários ascendentes, integrando um tetrâmetro iâmbico, enquanto o Knittelvers livre continuaria variando no número de sílabas, mas manteria os quatro acentos tônicos.

\footnotetext{
${ }^{8}$ Segundo Andreas HeuSLER (1956: 337), Goethe se utiliza sobretudo do Knittelvers livre, divergindo em dois sentidos da forma cultivada nos séculos XVI a XVII. Além de alterar o esquema rímico, variando a estrutura de rimas emparelhadas (aabb) por meio de cruzamento (abab) ou abraçamento (abba), Goethe permite que os versos de quatro acentos, masculinos ou femininos, sejam entremeados por versos de três acentos. No entanto, também há no Faust exemplos do Knittelvers estrito, de padrão iâmbico, adotado posteriormente por Busch como principal metro de suas histórias: „Und frágst du nóch, warúm dein Hérz / Sich báng in déinem Búsen klémmt? / Warúm ein únerklärter Schmérz / Dir álle Lébensrégung hémmt?" (Faust I, 4).
} 
Os tradutores do Fausto, de Goethe, em língua portuguesa, utilizaram - em sua maioria - o decassílabo como correspondência ao Knittelvers ${ }^{9}$, que ritmiza o drama desde o início, pontuando o célebre monólogo fáustico que a abre a tragédia de 1808 ("Hab nun, ach! Philosophie, / Juristerei und Medizin, / Und leider auch Theologie / Durchaus studiert, mit heißem Bemühn. Da stehe ich nun, ich armer Tor! / Und bin so klug als wie zuvor").

Nas traduções brasileiras dos poemas ilustrados de Wilhelm Busch, os padrões métricos utilizados como correspondência ao Knittelvers variam bem mais do que nas versões do Fausto para o português. Olavo Bilac, em Juca e Chico, e Guilherme de Almeida, na maior parte das histórias por ele traduzidas ${ }^{10}$, optam pela redondilha maior, em geral com acentos na $4^{\mathrm{a}} / 5^{\mathrm{a}}$ e na $7^{\mathrm{a}}$ sílabas. Esse padrão também é adotado por M. T. Cunha e por Sigfrid Frömming. Na adaptação do Knittelvers para o português, Cunha oscila, em diferentes histórias, entre redondilha maior, decassílabo e alexandrino. Já Antônio de Pádua Morse traduz todas as histórias em octossílabos, com acentos regulares na quarta e na oitava sílabas. De todos os tradutores de Busch no Brasil, Claudia Cavalcanti é a única que opta pela forma não metrificada. Quanto ao esquema rímico, todos os tradutores mantêm o emparelhamento do original.

Tentar desvendar o que motivou os tradutores a optar por um ou outro padrão métrico e acentual dificilmente ultrapassaria o limite da especulação. No entanto, valeria a pena refletir sobre as vantagens de se utilizarem, nas traduções de Busch, padrões métricos tão diferentes como a redondilha maior, forma corrente na poesia popular e em manifestações poéticas da tradição oral, como a literatura de cordel, e o decassílabo, padrão métrico elevado da poesia épica, utilizado em Os Lusíadas, de Camões, por exemplo, ou como metro correspondente ao pentâmetro shakesperiano na poesia lírica e a dramática.

A opção pela redondilha maior, sobretudo no contexto de traduções destinadas ao público infantil, traz a vantagem de resgatar uma fórmula métrica recorrente nas cantigas de roda, por exemplo, evocando um repertório rítmico associado ao lúdico e ao

\footnotetext{
${ }^{9} \mathrm{O}$ decassílabo é utilizado por Agostinho D'Ornellas, na primeira tradução de Faust. Eine Tragödie para o português, de 1867, por Sílvio Augusto de Bastos Meira (1968) e por João Barrento (1999). Divergem desse padrão Feliciano de Castilho (1872), que não traduziu a peça diretamente do alemão e opta pelo alexandrino, e Jenny Klabin Segall (1943), que traduz o Knittelvers em octossílabos.

${ }^{10}$ Entre as traduções da Guilherme de Almeida, as únicas que divergem do padrão da redondilha maior são "Corococó e Caracacá" e "O fantasma lambão", vertidas em octossílabos, com acentos regulares na quarta e na oitava sílabas.
} 
popular. Entre todos os padrões métricos adotados nas traduções de Busch no Brasil, a redondilha maior representa o mais breve de todos, obrigando o tradutor a uma economia verbal que pode conferir grande intensidade ao poema. Por outro lado, como correspondência ao Knittelvers, a opção pela redondilha maior oblitera a tradição do emprego desse padrão na poesia letrada de língua alemã.

A adoção do decassílabo como correspondência ao Knittelvers estrito buschiano, verificável apenas em parte das traduções de M. T. da Cunha, proporciona uma correspondência com a tradição da poesia de tom elevado evocada pelo padrão métricorímico do original. Além disso, a opção por um verso mais extenso pode oferecer um espaço maior para a elaboração do teor narrativo das histórias ilustradas de Busch. Ao contrário da redondilha maior, mais associada à oralidade, o decassílabo marca o vínculo de Wilhelm Busch com tradição poética letrada. Na Alemanha, seus poemas não se popularizaram como literatura recitada, mas sim como textos que só adquirem significação plena em relação aos desenhos e, portanto, dependem da apreensão óptica (e não apenas sonora) da obra.

Retomando as considerações sobre o humor buschiano, a adoção do decassílabo, além das vantagens já mencionadas, possibilita intensificar a discrepância entre texto e imagem. Enquanto as imagens narram situações banais, grotescas ou absurdas de forma esquemática, os versos épicos oferecem um contraponto elevado, intensificando o contraste imagético-verbal. Considerando que o decassílabo também está presente no hino nacional brasileiro, por exemplo, pode-se cogitar que até mesmo um público que não tenha tido contato com a poesia épica ou dramática de tom elevado tenderia a reconhecer nesse padrão métrico um tom solene, pelo menos subliminarmente.

Em diferença ao decassílabo de acentos irregulares, empregado por M. T. Cunha em algumas histórias, propõe-se aqui o decassílabo iâmbico, com o padrão de acentuação binária ascendente (fraco/forte) também adotado por Busch em sua ritmização uniformizadora do Knittelvers. Sem essa rigidez acentual, o emprego do padrão decassilábico tende a derivar para o tom prosaico e pouco rítmico que caracteriza alguns momentos das traduções de Cunha. A adoção de um esquema binário de acentuação, além de corresponder à sequência invariável de quatro iambos recorrente na grande maioria dos poemas ilustrados de Busch, acentua o caráter mecânico do texto, a contrastar com o dinamismo das imagens, o que remete à estratégia de criação de humor descrita por Bergson como "o mecânico agregado ao vivo". 
Com base nessa proposta, apresenta-se agora uma tradução de Hänsel und Gretel (1864), história que parodia o conto-de-fadas dos irmãos Grimm com o mesmo título, modificando-o por meio de reestruturações semânticas e de uma moldura pseudoedificante.

\section{Hänsel und Gretel ${ }^{11}$ : Maria e João. Tradução comentada}

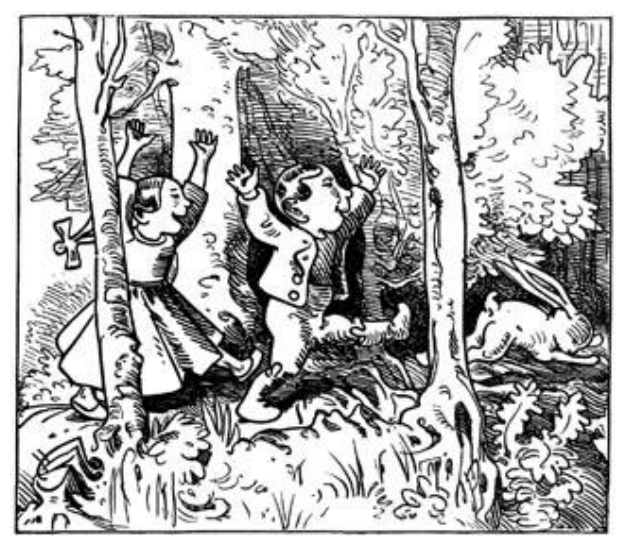

(1)

Ihr Kinder, spricht das Mütterlein, Geht ja nicht in den Wald hinein.

À porta, a mãe acena e admoesta:

"Meus filhos, fiquem longe da floresta!"12

\footnotetext{
${ }^{11}$ Original em alemão extraído de BUSCH 2002, vol.1.

${ }^{12} \mathrm{O}$ conto de fadas dos irmãos Grimm que funciona com o principal intertexto e dá nome a esta estória de Busch se intitula, nas traduções e adaptações brasileiras, "João e Maria" ou "Joãozinho e Maria". Aqui se inverte propositalmente os nomes ("Maria e João"), a fim de se ressaltar o fator paródico e as diversas inversões semânticas da história em relação ao conto de fadas. O fato de a sequência "Maria e João" poder ser lida como dois pés iâmbicos, a serem utilizados dentro do poema, também favorece essa opção. A tradução, de modo geral, também recorre a elementos visíveis apenas no desenho, considerando-os parte do texto. Essa estratégia é usada com grande liberdade por Guilherme de Almeida. O texto faz menção ao aceno da mãe, destacando o paralelismo visual com a imagem final da história, na qual a mãe se mostra com o mesmo gesto à porta, só que segurando um açoite. "Admoestar" é uma palavra possivelmente ignorada por leitores de faixas etárias inferiores. Essa opção, no entanto, poderia contribuir para ampliar o repertório lexical do leitor mais jovem. O uso esporádico de termos menos usuais e a mistura de registros lexicais também são recorrentes como artifício humorístico em Wilhelm Busch.
} 


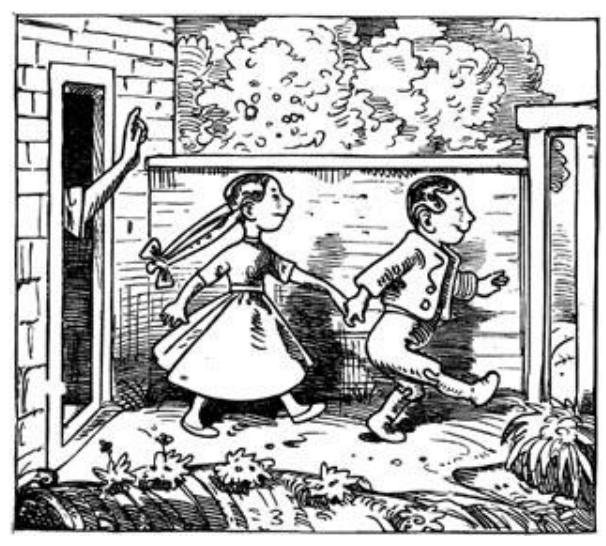

(2)

Ja Prosit! Wenn der Has' nicht wär'!

Gleich müssen sie dahinter her.

Mas vendo logo ali aquele coelho,

Os dois - iuhu! - se esquecem do conselho. ${ }^{13}$

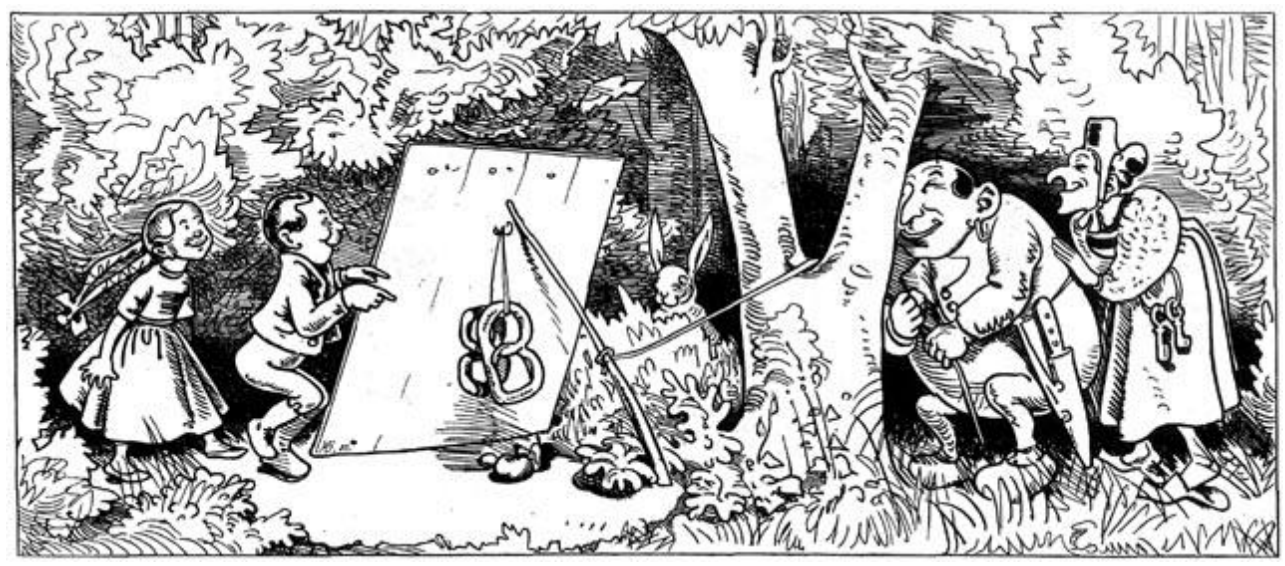

(3)

Nicht lange, eh' man's sich versah,

Steht schon die Kinderfalle da.

Oh, vejam! Bem no meio desta trilha,

Será biscoito? Ou é uma armadilha?!! ${ }^{14}$

\footnotetext{
${ }^{13}$ A tradução busca resgatar as interjeições do original, elemento de grande expressividade, em contraste com o tom geralmente neutro e contido das descrições de cena buschianas. Em diferença a Wilhelm Busch, que se utiliza de rimas ricas e raras, Olavo Bilac e Guilherme de Almeida recorrem também a rimas pobres em suas traduções. Na presente versão, segue-se o repertório rímico misto desses tradutores. No contexto decassilábico, a rima pobre cria um contraponto ao tom elevado e um estrato de menor elaboração poética, em contraste com o qual as rimas raras tendem a sobressair mais nitidamente.
} 


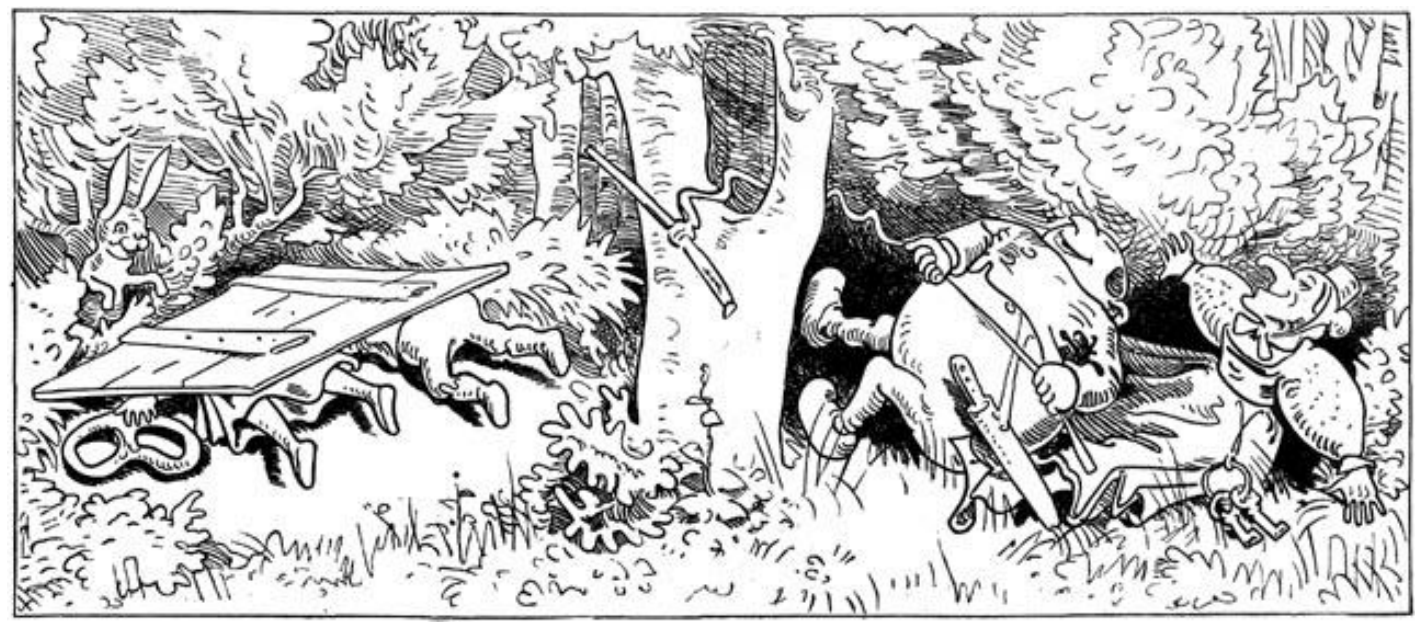

(4)

Die böse Hexe schreit: Nanu!

Perdatsch! Da fällt die Falle zu.

"Agora é a hora! Puxa!", grita a bruxa.

Kabam! E logo a dupla estrebucha. ${ }^{15}$

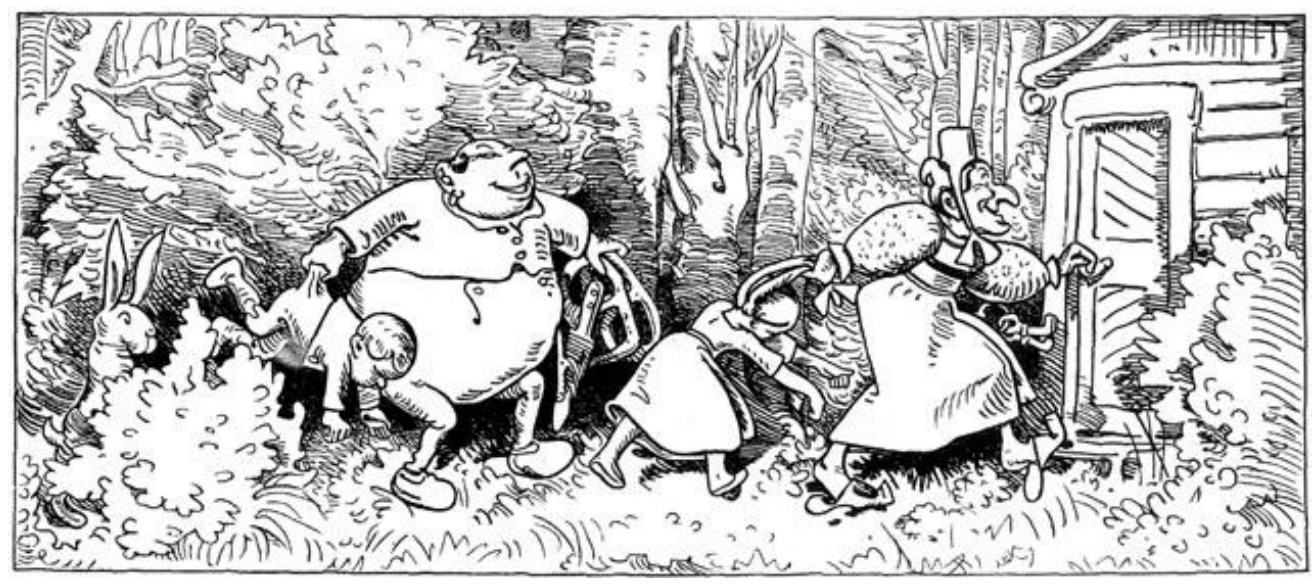

(5)

Und Hans und Gretel, ach, o Graus!

Schleppt man bis in das Hexenhaus.

Maria é arrastada no cangote;

E João - que horror! - puxado nos culotes. ${ }^{16}$

\footnotetext{
14 "Será biscoito ou é uma armadilha?": essa pergunta retórica pode servir para compensar a exclamação retórica não reproduzida na tradução do dístico anterior. "Biscoito": tradução de Brezel como "biscoito" ocorre em Guilherme de Almeida.

${ }^{15}$ No dístico anterior já se havia compensado a perda da rima rara na tradução deste. Neste quadro, a tradução intensifica as relações sonoras, paronomásias e rimas internas, remetendo a invocações mágicas.
} 


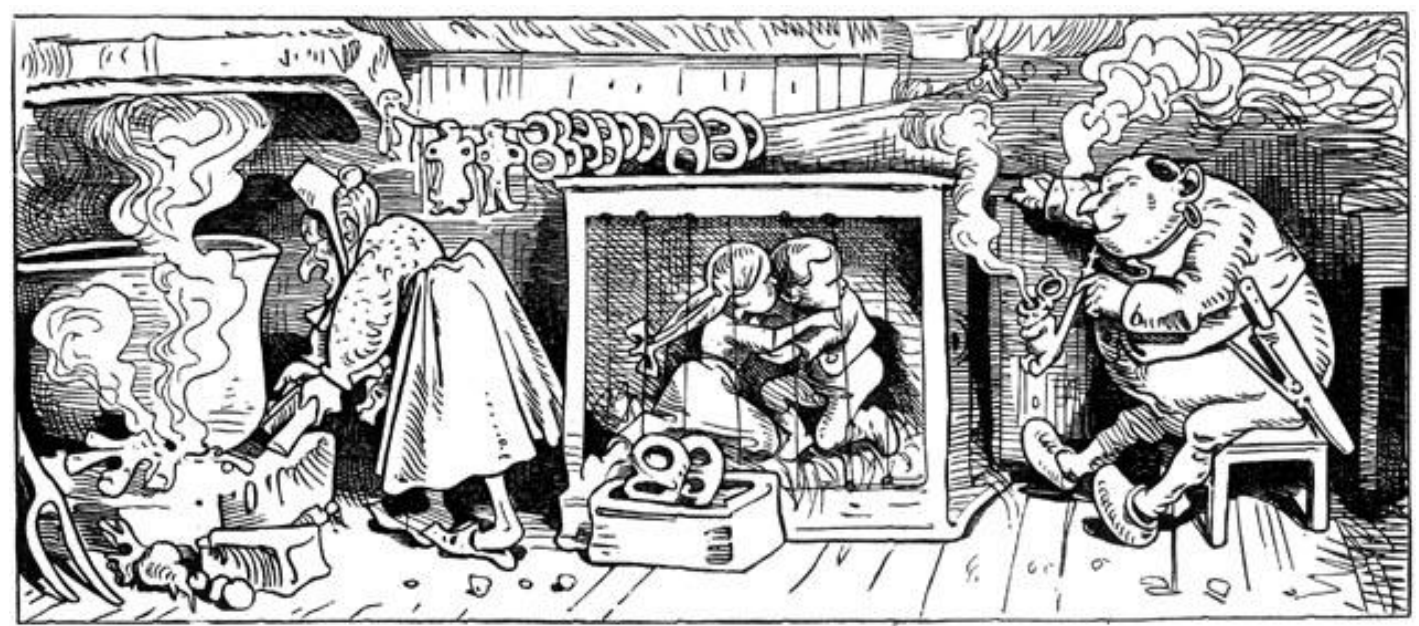

(6)

Die Hexe macht das Feuer an,

$\mathrm{Daß}$ sie die Kinder kochen kann.

Na casa, a bruxa acende o caldeirão,

P'ra cozinhar Maria e seu irmão. ${ }^{17}$

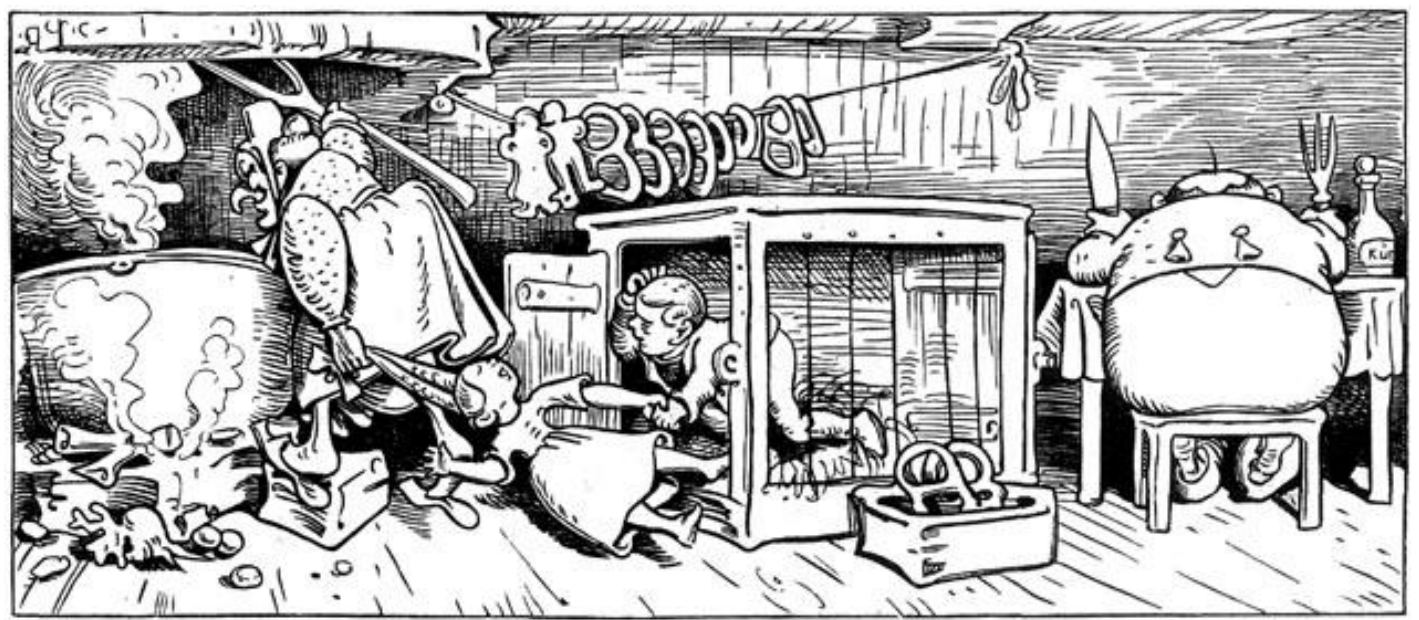

(7)

Am Tisch der dicke Bösewicht,

Der paßt schon auf sein Leibgericht.

O gordo malfeitor espera à mesa,

Enquanto a bruxa arrasta sua presa. ${ }^{18}$

\footnotetext{
${ }^{16}$ Aqui se opta por uma descrição de cena mais detalhada que o original. Descreve-se a forma como as crianças são levadas até a casa da bruxa, conforme demonstra a imagem. O paralelismo (neste caso entre Maria e João) é um recurso frequentemente utilizado por Busch, em texto e imagem.

${ }^{17}$ Nestes versos, recupera-se o termo "casa", omitido na tradução do dístico anterior. O "caldeirão", elemento ausente no texto original, é um atributo tradicional da bruxa, presente no desenho.
} 


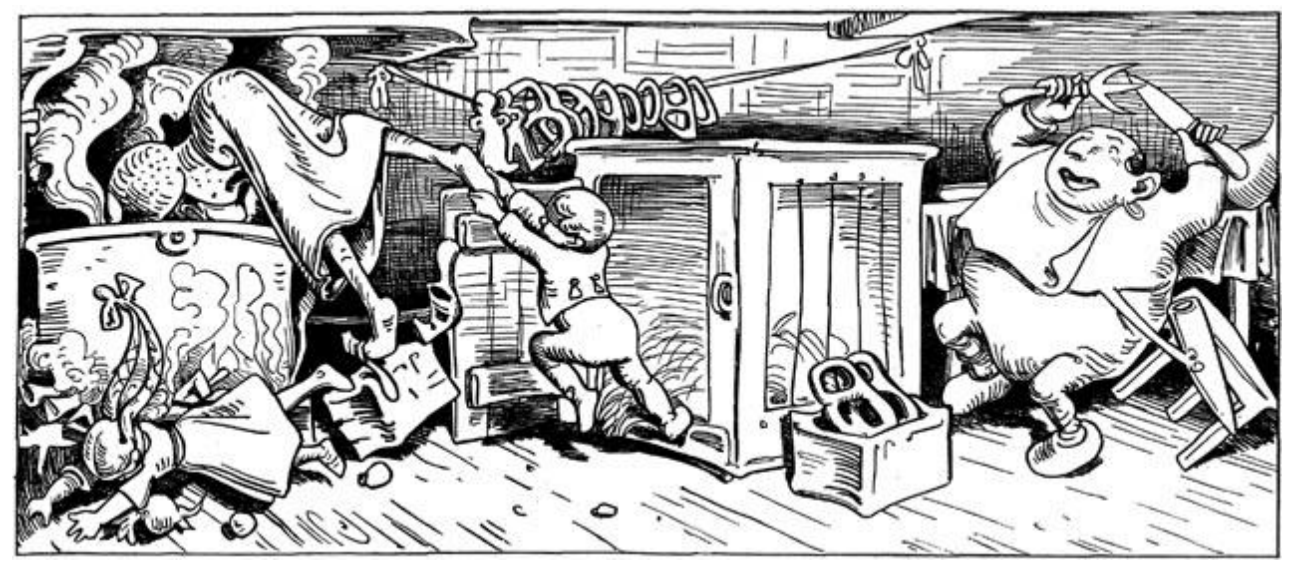

(8)

Doch Hänsel faßt die Hex' am Bein,

Plumps! fällt sie in den Topf hinein.

Feitiço vira contra a feiticeira:

É João que empurra a bruxa na caldeira. ${ }^{19}$

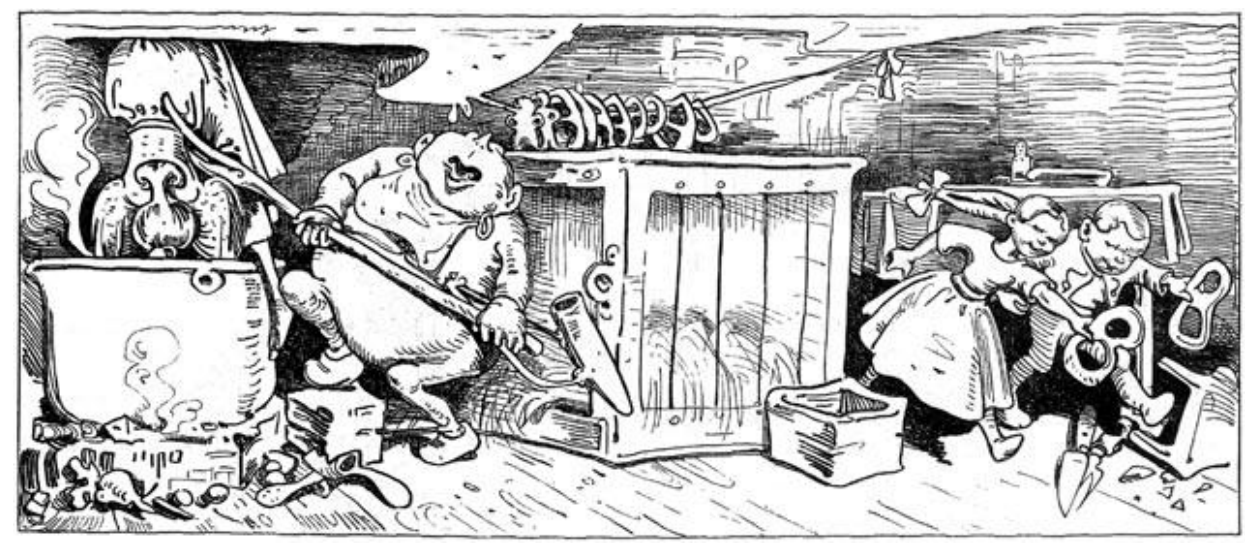

(9)

Die Hexe kriegte ihren Lohn,

Tot hängt sie an der Gabel schon.

E a feiticeira ganha o que merece:

Assim no garfo, presa, desfalece. ${ }^{20}$

\footnotetext{
${ }^{18} \mathrm{Na}$ tradução, descrevem-se paralelamente as ações do homem, que espera a comida, e da bruxa, que cozinha. A descrição de cena é uma das funções textuais mais recorrentes nas histórias ilustradas de Busch. A qualificação "presa" é revertida contra a bruxa no dístico 9. As palavras homófonas (substantivo e particípio do verbo "prender") destacam a inversão de papéis entre agressor e vítima, recorrente em Busch.

${ }^{19}$ Marcação do momento da reversão de papéis por meio de um dito popular: "o feitiço virou contra o feiticeiro", que - no caso - pode ser entendido em sentido figurado, mas também literal.

${ }^{20}$ A palavra "presa" regressa aqui, como adjetivo aplicado à bruxa, que - cenas antes (7) - havia tornado Maria sua "presa" (substantivo).
} 
Mello, Simone H. - Wilhelm Busch no Brasil

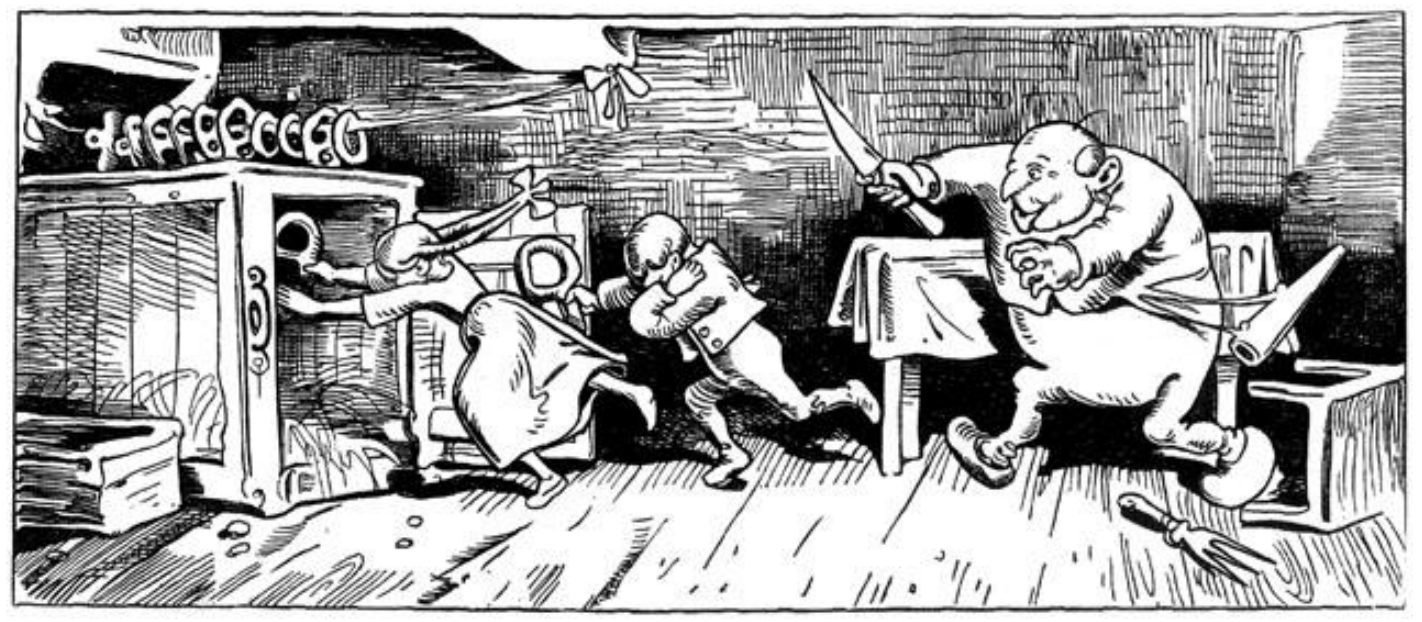

Der Menschenfresser, zornentbrannt,

Kommt mit dem Messer angerannt.

O canibal irado contra-ataca

E corre atrás dos dois com sua faca.

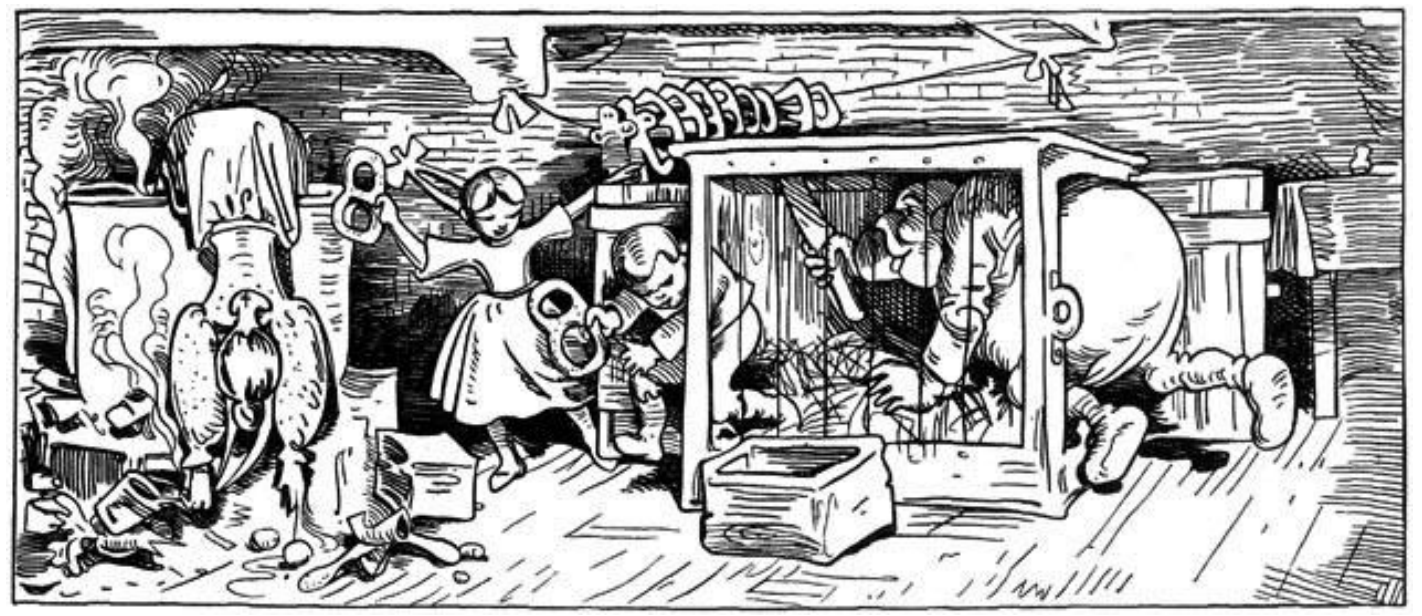

(11)

Im Kasten will er sie ertappen,

Der Kasten aber hat zwei Klappen.

Pretende aprisioná-los na gaiola,

Mas eles saem pela portinhola. 


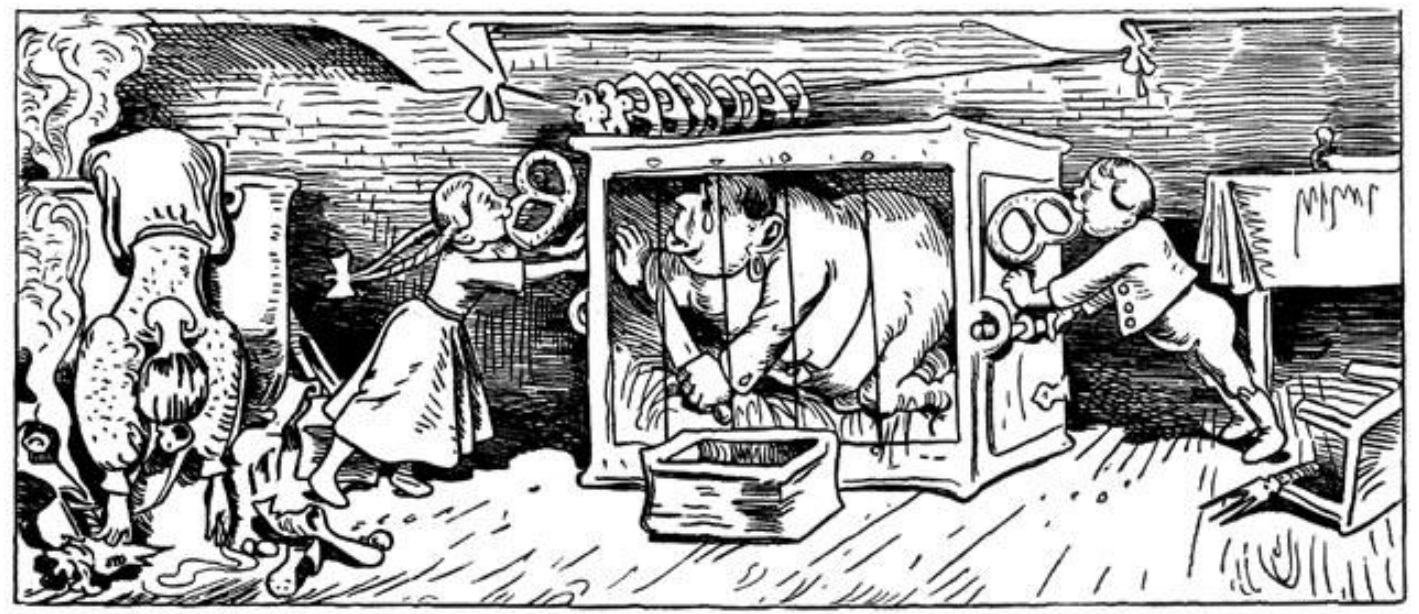

O weh! Das hat er nicht bedacht,

Nun wird der Käfig zugemacht.

Ai, ai! mas quem teria calculado?

Os dois o trancam dentro bem trancado. ${ }^{21}$
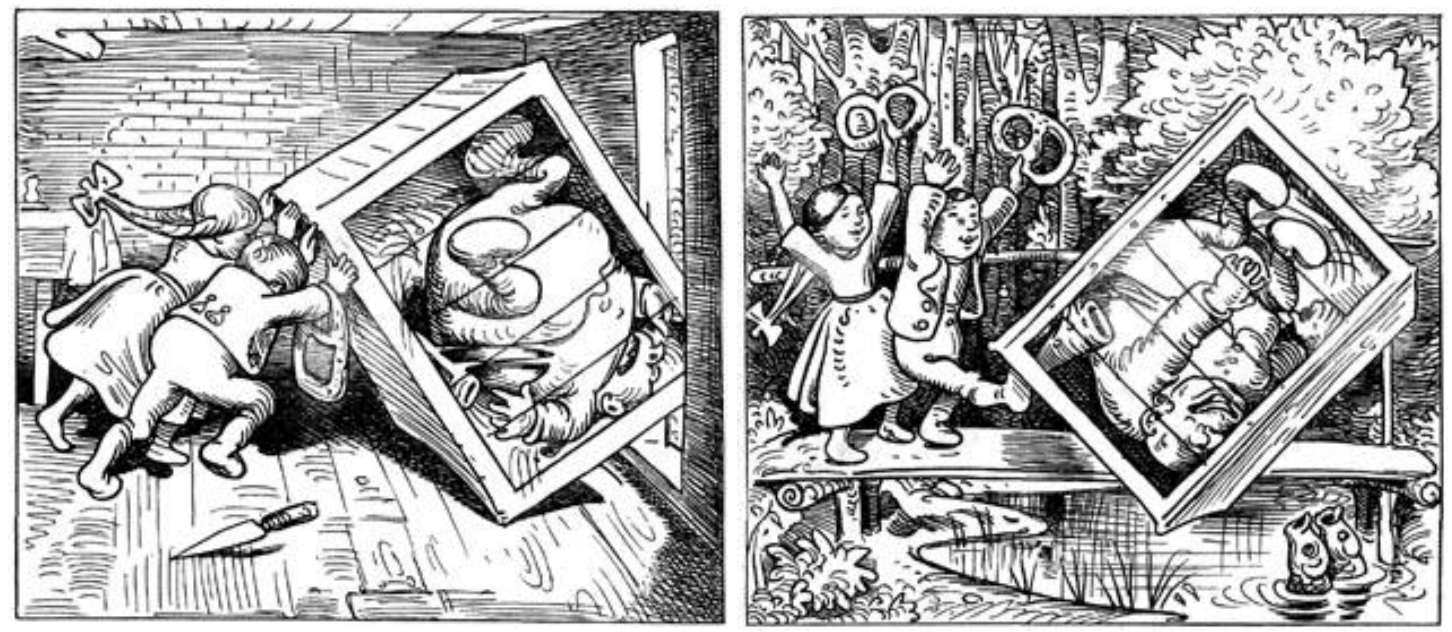

(13)

Der Dicke wird gerollt - und plumpf!

Schmeißt man ihn in den tiefen Sumpf.

O gordo - como pesa! mas que embate! -

Acaba dentro d'água. Iu-hu!! Auh! Platch! ${ }^{22}$

\footnotetext{
21 "Ai, ai! Mas quem teria calculado": pergunta retórica, recorrente em Busch, inclusive neste poema. A palavra "gaiola" já foi usada no dístico anterior.

${ }^{22}$ Neste dístico, tenta-se recuperar as interjeições e a rima rara (plumpf / Sumpf - "embate" / "platch"), entre substantivo e expressão onomatopaica. Essa rima só funcionaria para alguns sotaques brasileiros. Em Busch, no entanto, a coloração dialetal e o sotaque regional também são incorporados como elementos caricaturais.
} 


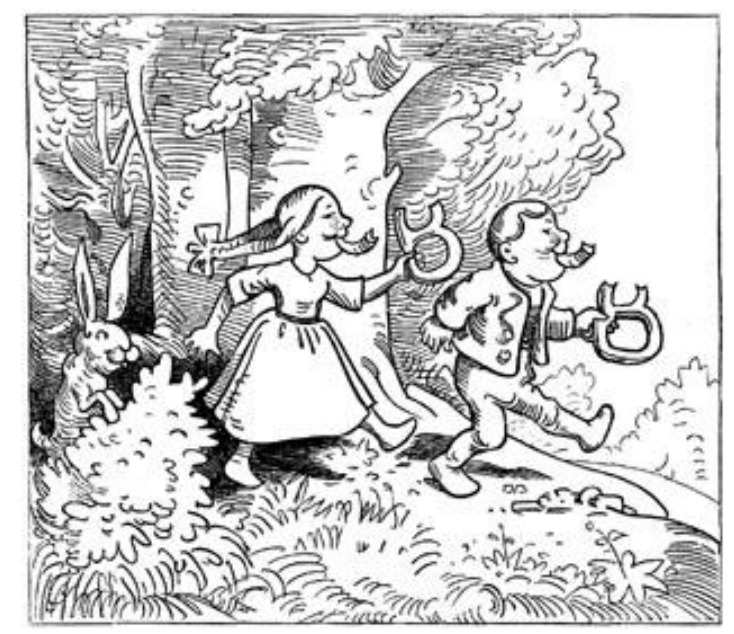

(14)

Jetzt gehn die zwei zum Wald hinaus,

Die Mutter schaut schon aus dem Haus;

Os dois, saindo - salvos! - da floresta...

A mãe, à porta, os vê através da fresta! ${ }^{23}$

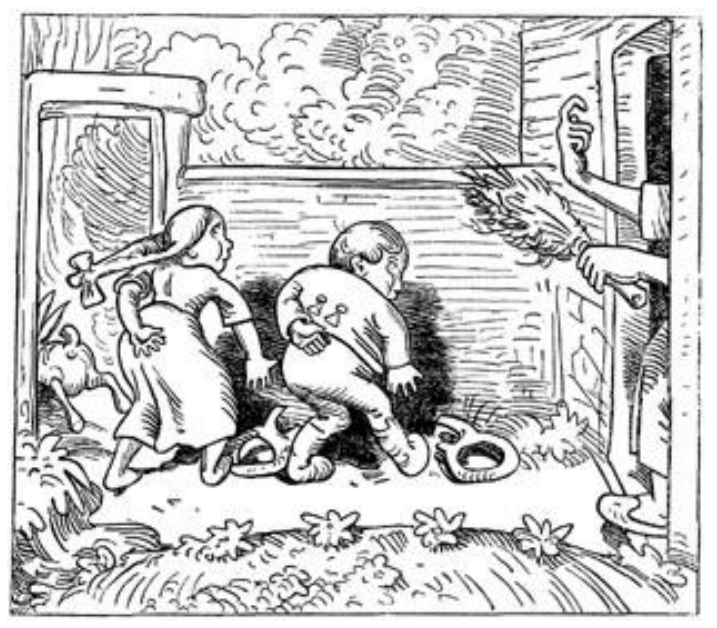

(15)

Sie winkt und läßt die Rute sehn:

Na, gute Nacht! Da dank' ich schön!

Mãezinha acena e deixa ver o açoite:

Já digo "durmam bem!" e "boa noite!"24

\footnotetext{
${ }^{23}$ Este dístico antecipa a imagem da mãe à espera, visível apenas no desenho posterior. Na tradução, enfatiza-se o paralelismo com a imagem da mãe, no primeiro de desenho, por meio da palavra "fresta", por onde ela acena às crianças, em sinal de advertência.
} 
A presente proposta de um novo modelo métrico-acentual para a tradução das histórias ilustradas de Wilhelm Busch vai ao encontro do horizonte teórico de Henri MESCHONNIC, que parte da indissociabilidade entre ritmo e significação.

Porque no ritmo [...] não se ouve o som, mas o assunto. Não é uma forma distinta do sentido. Traduzir, segundo o poema no discurso, é traduzir o recitativo, a narração da significância, a semântica prosódica e rítmica [...].(MESCHONNIC 2010: XXXII)

No caso dos poemas ilustrados buschianos, a discrepância entre texto e imagem colabora para a desestabilização do sentido, que não está fixado na letra, nem no desenho, mas sim na inter-relação dinâmica entre ambos. Resgatar, na tradução, essa dinâmica de significação implica recodificar o movimento rítmico do texto, a fim de reconstituir o contraponto irônico - não codificado verbalmente - que caracteriza as histórias. A opção pelo decassílabo iâmbico como correspondência ao Knittelvers resgata subliminarmente a tradição do verso heroico épico-dramático, gerando uma dissonância em relação à narrativa de imagens, que tende a se constituir mais como desdobramento gestual de uma cena do que como progressão de uma ação propriamente dita. O mero uso desse padrão métrico-acentual resgata a tradição de tom elevado e solene da poesia escrita, da mesma forma que o Knittelvers evoca referenciais literários importantes, como o Fausto, de Goethe. Nesse sentido, a definição de um parâmetro rítmico para a tradução implica necessariamente uma perspectivação histórico-literária e um diálogo com as traduções de Busch já existentes no Brasil.

Não se trata de buscar uma equivalência (conceito este descartado por Meschonnic) ao padrão original, mas sim de propor uma nova interpretação do papel do Knittelvers na poesia buschiana. Não são os elementos meramente formais (número de sílabas, posição dos acentos, uso da rima) que norteiam a opção pelo decassílabo, mas sim a relevância do padrão métrico-acentual para a dinâmica discursiva desse gênero híbrido que representam as histórias ilustradas de Busch. Dessa forma, fica claro que a preferência pelo decassílabo iâmbico, em detrimento da redondilha maior, reforça a escrita, e não a oralidade, como parâmetro de significação das histórias buschianas. Não

\footnotetext{
${ }^{24}$ Aqui se resgata o diminutivo de mãe, presente no primeiro dístico. Utilizado justamente na cena da ameaça de punição, o diminutivo intensifica a ironia do último quadro da história buschiana, que - ao contrário do conto de fada dos irmãos Grimm - não tem um final feliz, mesmo que termine como uma "história de ninar".
} 
Mello, Simone H. - Wilhelm Busch no Brasil

é, portanto, apenas a analogia histórico-literária entre ambos os padrões métricos que norteia a escolha, mas sim a descoberta da função que um novo ritmo pode adquirir na operação discursiva do poema.

O ritmo não muda nada no sentido lexical. Se ele muda alguma coisa, e muda necessariamente alguma coisa, já que tudo que chega ao discurso modifica o discurso, isto só pode ser no modo de significar. [...] Sua importância liga-se à enunciação, não ao enunciado. As próprias condições da enunciação transformam a significação (não o sentido) do enunciado. É tudo isso que deve se passar na tradução se ela quer levar em conta a enunciação. (MESCHONNIC 2010: 43)

A tentativa de potencializar a significação dos poemas, por meio de uma nova configuração rítmica, parte do empenho de se abrirem novos canais de acesso a um autor que teve o privilégio de ser traduzido por poetas integrantes do cânone literário brasileiro, mas ao mesmo tempo foi reduzido a um contexto de recepção muito restrito para a apreensão de sua complexidade literária.

\section{Anexo: Primeiras edições brasileiras de Wilhelm Busch}

\begin{tabular}{|c|c|c|c|c|c|c|}
\hline \multicolumn{7}{|c|}{ Fliegende Blätter } \\
\hline $\mathbf{N}^{\circ}$, ano & Título em alemão & $\begin{array}{l}\text { Título em } \\
\text { português }\end{array}$ & Tradutor & Livro & Série & Ano \\
\hline $\begin{array}{l}\text { FB 783, } \\
1860\end{array}$ & $\begin{array}{l}\text { Die Maus oder die } \\
\text { gestörte Nachtruhe }\end{array}$ & O camundongo & $\begin{array}{l}\text { Guilherme de } \\
\text { Almeida }\end{array}$ & $\begin{array}{l}\text { Corococó e } \\
\text { Caracacá e outras } \\
\text { histórias }\end{array}$ & Busch & 1943 \\
\hline $\begin{array}{l}\text { FB 841, } \\
1861\end{array}$ & $\begin{array}{l}\text { Die beiden Enten } \\
\text { und der Frosch }\end{array}$ & $\begin{array}{l}\text { O sapo e os dois } \\
\text { patinhos }\end{array}$ & $\begin{array}{l}\text { Guilherme de } \\
\text { Almeida }\end{array}$ & $\begin{array}{l}\text { Corococó e } \\
\text { Caracacá e outras } \\
\text { histórias }\end{array}$ & Busch & 1943 \\
\hline $\begin{array}{l}\text { FB 859, } \\
1861\end{array}$ & Die Fliege & A mosca & $\begin{array}{l}\text { Guilherme de } \\
\text { Almeida }\end{array}$ & $\begin{array}{l}\text { A mosca e outras } \\
\text { historietas }\end{array}$ & Busch & 1946 \\
\hline $\begin{array}{l}\text { FB 861, } \\
1862\end{array}$ & Der hohle Zahn & O dente furado & $\begin{array}{l}\text { Guilherme de } \\
\text { Almeida }\end{array}$ & $\begin{array}{l}\text { O fantasma lambão } \\
\text { e outras histórias }\end{array}$ & Busch & 1943 \\
\hline $\begin{array}{l}\text { FB 869, } \\
1862\end{array}$ & $\begin{array}{l}\text { Der zu wachsame } \\
\text { Hund }\end{array}$ & O cão fiel & $\begin{array}{l}\text { M.T. Cunha } \\
\text { Giácomo }\end{array}$ & $\begin{array}{l}\text { O trenó de } \\
\text { Joãozinho }\end{array}$ & $\begin{array}{l}\text { Juca e } \\
\text { Chico }\end{array}$ & 1976 \\
\hline $\begin{array}{l}\text { FB 881, } \\
1862\end{array}$ & $\begin{array}{l}\text { Diogenes und die } \\
\text { bösen Buben von } \\
\text { Korinth }\end{array}$ & $\begin{array}{l}\text { Diógenes e os } \\
\text { meninos de Corinto }\end{array}$ & $\begin{array}{l}\text { M.T. Cunha } \\
\text { Giácomo }\end{array}$ & $\begin{array}{l}\text { O fantasma lambão } \\
\text { e outras histórias }\end{array}$ & $\begin{array}{l}\text { Juca e } \\
\text { Chico }\end{array}$ & 1976 \\
\hline $\begin{array}{l}\text { FB 886, } \\
1862\end{array}$ & $\begin{array}{l}\text { Der Hahnenkampf, } \\
\text { eine Fabel }\end{array}$ & $\begin{array}{l}\text { Corococó e } \\
\text { Caracacá }\end{array}$ & $\begin{array}{l}\text { Guilherme de } \\
\text { Almeida }\end{array}$ & $\begin{array}{l}\text { Corococó e } \\
\text { Caracacá e outras } \\
\text { histórias }\end{array}$ & Busch & 1943 \\
\hline $\begin{array}{l}\text { FB 881, } \\
1862\end{array}$ & $\begin{array}{l}\text { Diogenes und die } \\
\text { bösen Buben von } \\
\text { Korinth }\end{array}$ & $\begin{array}{l}\text { Do philosopho } \\
\text { Diogenes e dos } \\
\text { máos meninos de } \\
\text { Corintho }\end{array}$ & $\begin{array}{l}\text { (não } \\
\text { identificado) }\end{array}$ & $\begin{array}{l}\text { Historias burlescas } \\
\text { e instructivas, em } \\
\text { versos coxos } \\
\text { esdruxolos, e de pé }\end{array}$ & & 1871 \\
\hline
\end{tabular}


Mello, Simone H. - Wilhelm Busch no Brasil

\begin{tabular}{|c|c|c|c|c|c|c|}
\hline & & & & $\begin{array}{l}\text { quebrado. (RJ: } \\
\text { Laemmert) }\end{array}$ & & \\
\hline $\begin{array}{l}\text { FB 906, } \\
1862\end{array}$ & $\begin{array}{l}\text { Die Rache des } \\
\text { Elephanten }\end{array}$ & $\begin{array}{l}\text { A vingança do } \\
\text { elefante }\end{array}$ & $\begin{array}{l}\text { M.T. Cunha } \\
\text { Giácomo }\end{array}$ & $\begin{array}{l}\text { O macaco e o } \\
\text { moleque }\end{array}$ & $\begin{array}{l}\text { Juca e } \\
\text { Chico }\end{array}$ & 1976 \\
\hline $\begin{array}{l}\text { FB 906, } \\
1862\end{array}$ & $\begin{array}{l}\text { Die Rache de } \\
\text { Elephanten }\end{array}$ & $\begin{array}{l}\text { Da vingança do } \\
\text { elephante da Africa }\end{array}$ & $\begin{array}{l}\text { (não } \\
\text { identificado) }\end{array}$ & $\begin{array}{l}\text { Historias burlescas } \\
\text { e instructivas, em } \\
\text { versos coxos } \\
\text { esdruxolos, e de pé } \\
\text { quebrado. (RJ: } \\
\text { Laemmert) }\end{array}$ & & 1871 \\
\hline $\begin{array}{l}\text { FB 912, } \\
1862\end{array}$ & $\begin{array}{l}\text { Die gestörte, aber } \\
\text { glücklich wieder } \\
\text { errungene Nachtruhe }\end{array}$ & $\begin{array}{l}\text { A pulga, uma } \\
\text { história sem } \\
\text { palavras }\end{array}$ & $\begin{array}{l}\text { (Guilherme } \\
\text { de Almeida) }\end{array}$ & $\begin{array}{l}\text { O camundongo e } \\
\text { outras historietas }\end{array}$ & Busch & 1943 \\
\hline $\begin{array}{l}\text { FB 913, } \\
1863\end{array}$ & $\begin{array}{l}\text { Ein Abenteuer in der } \\
\text { Neujahrsnacht oder } \\
\text { warum Herr } \\
\text { Brandmaier das } \\
\text { Punschtrinken für } \\
\text { immer verschworen } \\
\text { hat }\end{array}$ & $\begin{array}{l}\text { O que aconteceu na } \\
\text { noite de São } \\
\text { Silvestre ou por que } \\
\text { seu Fedolino deixou } \\
\text { para sempre o vício } \\
\text { de beber }\end{array}$ & $\begin{array}{l}\text { M.T. Cunha } \\
\text { Giácomo }\end{array}$ & $\begin{array}{l}\text { O fantasma lambão } \\
\text { e outras histórias }\end{array}$ & $\begin{array}{l}\text { Juca e } \\
\text { Chico }\end{array}$ & 1976 \\
\hline $\begin{array}{l}\text { FB 921, } \\
1863\end{array}$ & Die kluge Ratte & O rato sabido & $\begin{array}{l}\text { M. T. Cunha } \\
\text { Giácomo }\end{array}$ & $\begin{array}{l}\text { O fantasma lambão } \\
\text { e outras histórias }\end{array}$ & $\begin{array}{l}\text { Juca e } \\
\text { Chico }\end{array}$ & 1976 \\
\hline $\begin{array}{l}\text { FB 923, } \\
1863\end{array}$ & Der Schnuller & A chucha & $\begin{array}{l}\text { Antônio de } \\
\text { Pádua Morse }\end{array}$ & $\begin{array}{l}\text { O chorão e outras } \\
\text { histórias }\end{array}$ & Busch & 1953 \\
\hline $\begin{array}{l}\text { FB 930, } \\
1863\end{array}$ & Der zerstreute Rektor & $\begin{array}{l}\text { O professor } \\
\text { distraído }\end{array}$ & $\begin{array}{l}\text { M. T. Cunha } \\
\text { Giácomo }\end{array}$ & $\begin{array}{l}\text { O macaco e o } \\
\text { moleque }\end{array}$ & $\begin{array}{l}\text { Juca e } \\
\text { Chico }\end{array}$ & 1976 \\
\hline $\begin{array}{l}\text { FB, Supl. } \\
\text { Vol. XLIII, } \\
1865\end{array}$ & Der Virtuos & O grande virtuose & $\begin{array}{l}\text { Guilherme de } \\
\text { Almeida }\end{array}$ & $\begin{array}{l}\text { A mosca e outras } \\
\text { historietas }\end{array}$ & Busch & 1946 \\
\hline \multicolumn{7}{|c|}{ Münchener Bilderbogen } \\
\hline $\mathbf{N}^{\circ}$,ano & Título em alemão & $\begin{array}{l}\text { Título em } \\
\text { português }\end{array}$ & Tradutor & Livro & Série & Ano \\
\hline $\begin{array}{l}\text { MB 300-01, } \\
1861\end{array}$ & $\begin{array}{l}\text { Der Bauer und der } \\
\text { Windmüller }\end{array}$ & $\begin{array}{l}\text { O camponês e o } \\
\text { moleiro }\end{array}$ & $\begin{array}{l}\text { Guilherme de } \\
\text { Almeida }\end{array}$ & $\begin{array}{l}\text { Corococó e } \\
\text { Caracacá e } \\
\text { outras histórias }\end{array}$ & Busch & 1943 \\
\hline $\begin{array}{l}\text { MB 308, } \\
1861\end{array}$ & Das Rabennest & O ninho de urubu & $\begin{array}{l}\text { Guilherme de } \\
\text { Almeida }\end{array}$ & $\begin{array}{l}\text { O camundongo } \\
\text { e outras } \\
\text { historietas }\end{array}$ & Busch & 1943 \\
\hline $\begin{array}{l}\text { MB 316-17, } \\
1862\end{array}$ & $\begin{array}{l}\text { Der Bauer und sein } \\
\text { Schwein }\end{array}$ & $\begin{array}{l}\text { O porco e o } \\
\text { camponês }\end{array}$ & $\begin{array}{l}\text { M. T. Cunha } \\
\text { Giácomo }\end{array}$ & $\begin{array}{l}\text { O fantasma } \\
\text { lambão e outras } \\
\text { histórias }\end{array}$ & $\begin{array}{l}\text { Juca e } \\
\text { Chico }\end{array}$ & 1976 \\
\hline $\begin{array}{l}\text { MB 342, } \\
1863\end{array}$ & $\begin{array}{l}\text { Der Bauer und das } \\
\text { Kalb }\end{array}$ & $\begin{array}{l}\text { O caipira e seu } \\
\text { bezerro }\end{array}$ & $\begin{array}{l}\text { Guilherme de } \\
\text { Almeida }\end{array}$ & $\begin{array}{l}\text { O camundongo } \\
\text { e outras } \\
\text { historietas }\end{array}$ & Busch & 1943 \\
\hline $\begin{array}{l}\text { MB 361, } \\
1864\end{array}$ & $\begin{array}{l}\text { Der hinterlistige } \\
\text { Heinrich }\end{array}$ & Pedro Malvado & $\begin{array}{l}\text { Guilherme de } \\
\text { Almeida }\end{array}$ & $\begin{array}{l}\text { O camundongo } \\
\text { e outras } \\
\text { historietas }\end{array}$ & Busch & 1943 \\
\hline $\begin{array}{l}\text { MB 367, } \\
1864\end{array}$ & $\begin{array}{l}\text { Der Affe und der } \\
\text { Schusterjunge }\end{array}$ & $\begin{array}{l}\text { O macaco e o } \\
\text { moleque }\end{array}$ & $\begin{array}{l}\text { M. T. Cunha } \\
\text { Giácomo }\end{array}$ & $\begin{array}{l}\mathrm{O} \text { macaco e o } \\
\text { moleque }\end{array}$ & $\begin{array}{l}\text { Juca e } \\
\text { Chico }\end{array}$ & 1976 \\
\hline $\begin{array}{l}\text { MB 370, } \\
1864\end{array}$ & Die Rutschpartie & O trenó do Joãozinho & $\begin{array}{l}\text { M. T. Cunha } \\
\text { Giácomo }\end{array}$ & $\begin{array}{l}\text { O trenó do } \\
\text { Joãozinho }\end{array}$ & $\begin{array}{l}\text { Juca e } \\
\text { Chico }\end{array}$ & 1976 \\
\hline $\begin{array}{l}\text { MB 376, } \\
1864\end{array}$ & Adelens Spaziergang & O passeio de Adélia & $\begin{array}{l}\text { M. T. Cunha } \\
\text { Giácomo }\end{array}$ & $\begin{array}{l}\text { O trenó do } \\
\text { Joãozinho }\end{array}$ & $\begin{array}{l}\text { Juca e } \\
\text { Chico }\end{array}$ & 1976 \\
\hline $\begin{array}{l}\text { MB } \\
427 / 428,\end{array}$ & Zwei Diebe & Os dois ladrões & Guilherme de & $\begin{array}{l}\text { O fantasma } \\
\text { lambão e outras }\end{array}$ & Busch & 1943 \\
\hline
\end{tabular}


Mello, Simone H. - Wilhelm Busch no Brasil

\begin{tabular}{|c|c|c|c|c|c|c|c|c|c|c|}
\hline \multicolumn{2}{|l|}{1866} & & & & Alm & & his & rias & & \\
\hline \multicolumn{2}{|l|}{$\begin{array}{l}\text { MB 436, } \\
1867\end{array}$} & $\begin{array}{l}\text { Der neidische } \\
\text { Handwerksbursch }\end{array}$ & \multicolumn{2}{|c|}{$\begin{array}{l}\text { Do rico comilão e do } \\
\text { pobretão invejoso }\end{array}$} & \multicolumn{2}{|c|}{$\begin{array}{l}\text { (não } \\
\text { identificado) }\end{array}$} & \multicolumn{2}{|c|}{$\begin{array}{l}\text { Historias } \\
\text { burlescas e } \\
\text { instructivas, em } \\
\text { versos coxos } \\
\text { esdruxolos, e de } \\
\text { pé quebrado. } \\
\text { (RJ: Laemmert) }\end{array}$} & & 1871 \\
\hline \multicolumn{2}{|l|}{$\begin{array}{l}\text { MB 472, } \\
1868\end{array}$} & $\begin{array}{l}\text { Vetter Franz auf dem } \\
\text { Esel }\end{array}$ & \multicolumn{2}{|c|}{$\begin{array}{l}\text { O primo Chico e o } \\
\text { burro }\end{array}$} & \multicolumn{2}{|c|}{$\begin{array}{l}\text { Guilherme de } \\
\text { Almeioda }\end{array}$} & \multicolumn{2}{|c|}{$\begin{array}{l}\text { O fantasma } \\
\text { lambão e outras } \\
\text { histórias }\end{array}$} & Busch & 1943 \\
\hline \multicolumn{2}{|l|}{$\begin{array}{l}\text { MB 474, } \\
1868\end{array}$} & Die Verwandlung & \multicolumn{2}{|c|}{ O lambe-lambe } & \multicolumn{2}{|c|}{$\begin{array}{l}\text { Guilherme de } \\
\text { Almeida }\end{array}$} & \multicolumn{2}{|c|}{$\begin{array}{l}\text { Corococó e } \\
\text { caracacá e } \\
\text { outras histórias }\end{array}$} & Busch & 1943 \\
\hline \multicolumn{2}{|l|}{$\begin{array}{l}\mathrm{MB} \\
527 / 528, \\
1870\end{array}$} & Die Brille & \multicolumn{2}{|l|}{ Os óculos } & \multicolumn{2}{|c|}{$\begin{array}{l}\text { Antônio de } \\
\text { Pádua Morse }\end{array}$} & \multicolumn{2}{|c|}{$\begin{array}{l}\text { O chorão e } \\
\text { outras histórias }\end{array}$} & Busch & 1953 \\
\hline \multicolumn{2}{|l|}{$\begin{array}{l}\text { MB 562, } \\
1872\end{array}$} & $\begin{array}{l}\text { Eugen, der } \\
\text { Honigschlecker }\end{array}$ & \multicolumn{2}{|c|}{ O fantasma lambão } & \multicolumn{2}{|c|}{$\begin{array}{l}\text { Guilherme de } \\
\text { Almeida }\end{array}$} & \multicolumn{2}{|c|}{$\begin{array}{l}\text { O fantasma } \\
\text { lambão e outras } \\
\text { histórias }\end{array}$} & Busch & 1943 \\
\hline \multicolumn{11}{|c|}{ Über Land und Meer } \\
\hline \multicolumn{2}{|l|}{$\mathbf{N}^{\circ}$, ano } & Título em alemão & \multicolumn{2}{|l|}{$\begin{array}{l}\text { Título em } \\
\text { português }\end{array}$} & \multicolumn{2}{|c|}{ Tradutor } & \multicolumn{2}{|l|}{ Livro } & Série & Ano \\
\hline \multicolumn{2}{|c|}{$\begin{array}{l}\text { ÜLM 19, } \\
1867\end{array}$} & $\begin{array}{l}\text { Hans Huckbein, der } \\
\text { Unglücksrabe }\end{array}$ & \multicolumn{2}{|l|}{ O corvo } & \multicolumn{2}{|c|}{$\begin{array}{l}\text { Antônio de } \\
\text { Pádua Morse }\end{array}$} & $\begin{array}{l}\text { O corv } \\
\text { coelhit }\end{array}$ & $\begin{array}{l}\text { e o } \\
\text { lo da sorte }\end{array}$ & Busch & 1952 \\
\hline $\begin{array}{l}\text { ÜLM } 23 \\
1869 / 197\end{array}$ & & Der Schreihals & O chorão & & $\begin{array}{l}\text { Antôn } \\
\text { Pádua }\end{array}$ & $\begin{array}{l}\text { de } \\
\text { orse }\end{array}$ & $\begin{array}{l}\text { O corv } \\
\text { coelhir }\end{array}$ & $\begin{array}{l}\text { e o } \\
\text { lo da sorte }\end{array}$ & Busch & 1952 \\
\hline Die illus & rierte $V$ & Welt & & & & & & & & \\
\hline $\mathbf{N}^{\circ}$, ano & & Título em alemão & $\begin{array}{l}\text { Título em } \\
\text { português }\end{array}$ & & Tradu & & Livro & & Série & Ano \\
\hline $\begin{array}{l}\text { IW 17, } \\
1867 / 18\end{array}$ & & Die Prise & A pitada de & & $\begin{array}{l}\text { Guilhe } \\
\text { Almei }\end{array}$ & ne de & $\begin{array}{l}\text { A mos } \\
\text { histori }\end{array}$ & $\begin{array}{l}\text { a e outras } \\
\text { as }\end{array}$ & Busch & 1946 \\
\hline Daheim & & & & & & & & & & \\
\hline $\begin{array}{l}\text { Númer } \\
\text { o, ano }\end{array}$ & Títul & lo em alemão & $\begin{array}{l}\text { Título em } \\
\text { português }\end{array}$ & & Tradu & & Livro & & Série & Ano \\
\hline $\begin{array}{l}\mathrm{Dh}, \\
1868\end{array}$ & Der $\mathrm{V}$ & Wurstdieb & O furta-lings & & $\begin{array}{l}\text { Guilhe } \\
\text { Almei }\end{array}$ & ne de & $\begin{array}{l}\text { A mos } \\
\text { histori }\end{array}$ & $\begin{array}{l}\text { a e outras } \\
\text { as }\end{array}$ & Busch & 1946 \\
\hline Coletân & as de $h$ & histórias & & & & & & & & \\
\hline $\begin{array}{l}\text { Lugar, e } \\
\text { ano }\end{array}$ & litora, & $\begin{array}{l}\text { Título da } \\
\text { história } \\
\text { em alemão }\end{array}$ & Coletânea & $\begin{array}{l}\text { Títul } \\
\text { portı }\end{array}$ & $\begin{array}{l}\text { em } \\
\text { guês }\end{array}$ & Tradt & & Livro & Série & Ano \\
\hline $\begin{array}{l}\text { Heidelbe } \\
\text { Basserm } \\
1874\end{array}$ & & Der Zylinder & Dideldum! & A car & tola & $\begin{array}{l}\text { Guilh } \\
\text { Almei }\end{array}$ & $\begin{array}{l}\text { me de } \\
\text { a }\end{array}$ & A cartola & Busch & 1949 \\
\hline $\begin{array}{l}\text { Heidelbe } \\
\text { Basserm } \\
1877 / 18\end{array}$ & & $\begin{array}{l}\text { Eine kalte } \\
\text { Geschichte }\end{array}$ & $\begin{array}{l}\text { Die } \\
\text { Haarbeutel }\end{array}$ & $\begin{array}{l}\text { Estór } \\
\text { gelad }\end{array}$ & & $\begin{array}{l}\text { Guilh } \\
\text { Almei }\end{array}$ & $\begin{array}{l}\text { me de } \\
\text { a }\end{array}$ & A cartola & Busch & 1949 \\
\hline $\begin{array}{l}\text { Heidelbe } \\
\text { Basserm } \\
1877 / 18\end{array}$ & & $\begin{array}{l}\text { Eine milde } \\
\text { Geschichte }\end{array}$ & $\begin{array}{l}\text { Die } \\
\text { Haarbeutel }\end{array}$ & $\mathrm{O}$ be & errão & $\begin{array}{l}\text { Guilh } \\
\text { Almei }\end{array}$ & $\begin{array}{l}\text { me de } \\
\text { a }\end{array}$ & A cartola & Busch & 1949 \\
\hline $\begin{array}{l}\text { Heidelbe } \\
\text { Basserm } \\
1881\end{array}$ & & Der Fuchs & $\begin{array}{l}\text { Der Fuchs. } \\
\text { Die } \\
\text { Drachen. }\end{array}$ & A rap & & $\begin{array}{l}\text { M. T. } \\
\text { Giáco }\end{array}$ & unha & $\begin{array}{l}\text { O macaco e } \\
\text { o moleque }\end{array}$ & $\begin{array}{l}\text { Juca e } \\
\text { Chico }\end{array}$ & 1976 \\
\hline
\end{tabular}


Mello, Simone H. - Wilhelm Busch no Brasil

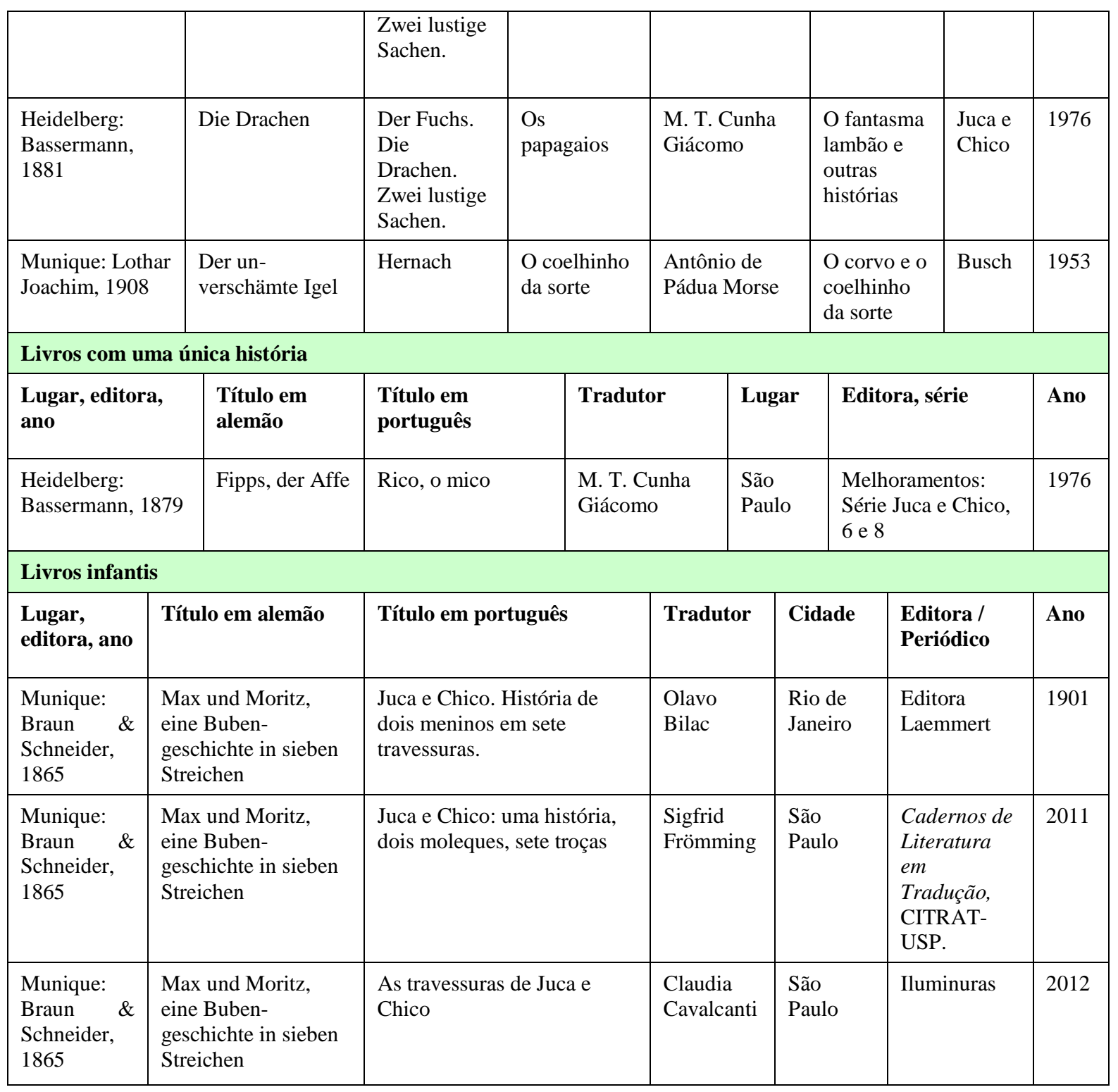

\section{Referências bibliográficas}

BERGSON, Henri. Le rire - Essai sur la signification du comique. Paris, Éditions Alcan, 1924.

BusCH, Wilhelm. Die Bildergeschichten - Historisch-kritische Gesamtausgabe. Vol. 1. Org. Hans Joachim Neyer e Herwig Guratzsch. Hannover, Schlütersche Buchhandlung, 2002.

FRÖMMING, Sigfrid. Aplicação da teoria de Peeter Torop à tradução da obra de literatura infantil Max und Moritz, de Wilhelm Busch, do alemão ao português do Brasil. Dissertação de mestrado em Estudos da Tradução, Universidade Federal de Santa Catarina - Centro de Comunicação e Expressão, Departamento de Língua e Literatura Estrangeiras, Florianópolis, 2009.

. Max und Moritz: uma tradução comentada. In: Cadernos de literatura em tradução, 12, 2011, s/p. http://www.revistas.usp.br/clt/article/view/49542/53617

HEUSLER, Andreas. Deutsche Versgeschichte. Vol. 3. Berlim, Walter de Gruyter \& Co., 1956. 
Mello, Simone H. - Wilhelm Busch no Brasil

KraUS, Joseph. Wilhelm Busch. Mit Selbstzeugnissen und Bilddokumenten. Reinbek bei Hamburg, Rowohlt, 2009

Meschonnic, Henri. Poética do Traduzir. Trad. Jerusa Pires Ferreira Suely Fenerich. São Paulo, Editora Perspectiva, 2010.

PAPE, Walter. Wilhelm Busch (Realien zur Literatur, Sammlung Metzler 163). Stuttgart, Metzler, 1977.

POMARI, Gerson Luís. O pintor e o poeta: Wilhelm Busch no Brasil. Dissertação de mestrado. 2. vols. Assis: Universidade Estadual Paulista Júlio de Mesquita Filho, Faculdade de Ciências e Letras, Teoria Literária e Literatura Comparada, 1999.

. Vício e verso - As histórias ilustradas de Wilhelm Busch no sistema literário brasileiro. Tese de doutorado. Universidade de São Paulo, Faculdade de Filosofia, Letras e Ciências Humanas, Departamento de Letras Modernas, Programa de Pós-Graduação em Literatura Alemã, 2008.

Recebido em 09/08/2014 aceito em 08/10/2014 